\title{
Environmental indicators in effluent assessment of rainbow trout (Oncorhynchus mykiss) reared in raceway system through phosphorus and nitrogen
}

\author{
M. A. B. Moraes ${ }^{a}$, C. F. Carmo ${ }^{a}$, Y. A. Tabata ${ }^{b}$, A. M. Vaz-dos-Santos ${ }^{c}$ and C. T. J. Mercante
}

${ }^{a}$ Centro de Pesquisa e Desenvolvimento Especializado em Recursos Hídricos, Instituto de Pesca - IP, Avenida Francisco Matarazzo, 455, Parque da Água Branca, CP 61070, CEP 05001-900, São Paulo, SP, Brazil

'Estação Experimental de Salmonicultura, Agência Paulista de Tecnologia dos Agronegócios - APTA, Parque Estadual de Campos do Jordão, CP 361, CEP 12460-000, Campos do Jordão, SP, Brazil

'Laboratório de Esclerocronologia, Universidade Federal do Paraná - UFPR, Rua Pioneiro, 2153, CEP 85950-000, Palotina, PR, Brazil

*e-mail: muniquebio@gmail.com

Received: May 6, 2015 - Accepted: July 7, 2015 - Distributed: November 30, 2016

(With 4 figures)

\begin{abstract}
The phosphorus and nitrogen discharge via effluent of intensive trout farming system was quantified through the use of environmental indicators. The nutrient loads, the mass balance, the estimated amount of nutrients in feed and the amount of nutrients converted in fish biomass were calculated based on the concentrations of phosphorus $(\mathrm{P})$ and nitrogen $(\mathrm{N})$ in the feed and in the water. Of the offered feed, $24.75 \mathrm{~kg}$ were available as $\mathrm{P}$ and $99.00 \mathrm{~kg}$ as N , of these, $9.32 \mathrm{~kg} \mathrm{P}(38 \%)$ and $29.12 \mathrm{~kg} \mathrm{~N}(25 \%)$ were converted into fish biomass and $15.43 \mathrm{~kg} \mathrm{P}(62 \%)$ and $69.88 \mathrm{~kg} \mathrm{~N}(75 \%)$ were exported via effluent. The loads and the mass balance show the excessive discharge of nutrients via effluent, corroborated by the feed conversion ratio (2.12:1) due to the low efficiency of feed utilization, therefore, it is proposed the use of this zootechnical parameter as environmental indicator. In addition, feed management practices are not adequate, highlighting the low frequency of feeding during the day, excessive amount and low quality of feed offered. These results demonstrate the need for adequate feed management and the need for careful monitoring of effluent.
\end{abstract}

Keywords: nutrients loads, mass balance, feed conversion ratio, eutrophication, Oncorhynchus mykiss (Walbaum).

\section{Indicadores ambientais na avaliação de efluentes de truta arco-íris (Oncorhynchus mykiss) criados em sistema de raceway através do fósforo e nitrogênio}

\begin{abstract}
Resumo
A descarga de fósforo e nitrogênio via efluente do sistema intensivo de truticultura foi quantificada através da utilização de indicadores ambientais. As cargas de nutrientes, o balanço de massa, a quantidade estimada de nutrientes na ração e a quantidade de nutrientes convertidos em biomassa de peixes foram calculados com base nas concentrações de fósforo (P) e nitrogênio (N) na ração e na água. Da ração oferecida, $24,75 \mathrm{~kg}$ estavam disponíveis como P e 99,00 kg como $\mathrm{N}$, destes, $9,32 \mathrm{~kg}$ de $\mathrm{P}(38 \%)$ e $29,12 \mathrm{~kg}$ de N (25\%) foram convertidos em biomassa de peixe e $15,43 \mathrm{~kg} \mathrm{P}(62 \%)$ e $69,88 \mathrm{~kg} \mathrm{~N}(75 \%)$ foram exportados via efluente. As cargas e o balanço de massa mostram a descarga excessiva de nutrientes via efluente, corroborado pela taxa de conversão alimentar $(2,12: 1)$, devido à baixa eficiência na utilização da ração, portanto, propõe-se a utilização deste parâmetro zootécnico como indicador ambiental. Além disso, as práticas de manejo alimentar não são adequadas, destacando a baixa frequência de alimentação durante o dia, quantidade excessiva e baixa qualidade da alimentação ofertada. Esses resultados demonstram a necessidade de manejo alimentar adequado e de monitoramento do efluente.
\end{abstract}

Palavras-chave: cargas de nutrientes, balanço de massa, taxa de conversão alimentar, eutrofização, Oncorhynchus mykiss (Walbaum).

\section{Introduction}

The annual export of nutrients to the environment arising from inland aquaculture in 2010 was approximately one million ton of phosphorus $(\mathrm{P})$ and five million tons

of nitrogen (N) (Bouwman et al., 2013). These residues discharged via effluent, through the culture of aquatic organisms, may present high pollution potential of the 
receiving water bodies (Koçer et al., 2013; Henares and Camargo, 2014).

The trout farming, if not well managed, shows potential for excessive discharge of nutrients which has its origin, mainly, in the feed introduced into the system, either directly by dispersing or the metabolic products generated by fish (Amirkolaie, 2011). This potential depends on the size of the production system, the amount of biomass, the nature and volume of water used, management practices and feed quality that is offered to the fish (Boaventura et al., 1997).

The feed is the most important parameter related to the environmental impact (Bureau et al., 2003; Wang et al., 2012), because of the total phosphorus and nitrogen supplied in the diet, about $30 \%$ will be present in the cultured biomass of the organisms and the remainder goes to the receiving water body via effluent (Baird et al., 1996), with capacity of causing the eutrophication process. Therefore, there may be greater or smaller losses of these nutrients, important in animal metabolism, to the environment depending on content and form that are in the diet, associated to the quality and amount of feed (Araripe et al., 2006).

Some industries have produced diets with low quality to be sold at lower prices, which can lead to the use of diets with low digestibility and inadequate levels of nutrients (Abimorad et al., 2012). This associated to the excessive feed offered impairs the production (reduced growth rate) and consequently increases the excretion of nutrients into the environment, causing the deterioration of water quality via the receiving water body enrichment by the nitrogenous and phosphate compounds (Noroozrajabi et al., 2013). Therefore, the allocated feed should be proportional to the consumption of organisms and be of high quality.

In countries as Denmark, Norway and the United States of America, where strict environmental regulations governing the operation of trout farming, the phosphorus content in the diet of trout and feed conversion ratio (FCR) cannot exceed $0.9-1.0 \%$ and 1.0, respectively (Bergheim and Brinker, 2003; MacMillan et al., 2003). However, in Brazil, there is no legislation that considers the nutrient content in the feed composition as a proposal to reduce the environmental impact. The National Environmental Council, federal collegiate of the Environment Ministry, provides for the classification of water bodies and environmental guidelines for its framework, as well as establishes the conditions and discharge standards of the effluent through the resolutions 357 of 2005 and 430 of 2011, i.e., regulates the limit allowed of nutrient concentrations in effluent discarded in accordance to the framework of the water body (Brasil, 2005, 2011).

Considering this scenario and the fact that the environmental impact of effluent from the aquaculture is an increasing issue of concern around the world, it is clear the importance of the environment conservation and the care that must be taken with the rational use of water resources (Gorlach-Lira et al., 2013; FAO, 2014). Therefore, it is necessary evaluation of the efficiency with which feed, nutrients and water are used in aquaculture. For this evaluation is suggested the application of environmental indicators in aquaculture systems in order to estimate the environmental performance of the production system, assessing the efficiency with which resources are used (Boyd and Queiroz, 2001; Boyd et al., 2007).

Among the environmental indicators suggested by these authors, this study apply: a) nutrient load (relation between water flow and nutrient concentrations in affluent and effluent of the system); b) mass balance (quantitative description of all materials that enter, leave and accumulate in system with defined borders); c) input of nutrients via feed $\left(\mathrm{I}_{\mathrm{F}}\right)$; ) converted nutrients in fish biomass $\left(\mathrm{N}_{\mathrm{B}}\right)$.

Thus, the aim of this study was to use the environmental indicators as a method to quantify the discharge of phosphorus and nitrogen via effluent of intensive trout farming system.

\section{Material and Methods}

\subsection{Study area}

The present study was performed in intensive trout farming system, located in National Park of Serra da Bocaina, $35 \mathrm{~km}$ away from Bananal city, São Paulo State (SP), Brazil, in Hydrographic Basin Paraíba do Sul situated 1,160 meters above sea level (22 ${ }^{\circ} 50^{\prime} 03.92$ "S and $\left.44^{\circ} 25^{\prime} 46.33^{\prime \prime} \mathrm{W}\right)$. Atlantic forest area covering large part of the springs that provide potable water to the population, located in tropical and subtropical region, in the mountainous regions where temperatures are close to $22{ }^{\circ} \mathrm{C}$ in the hottest month. The stream that supplies the trout farming system was classified as class I according to the current legislation (Brasil, 2005) with average flow of $72 \mathrm{~L} \mathrm{~s}^{-1}$. During the study period, more than $50 \%$ of the stream flow was diverted into the fish farm.

\subsection{Description of production system and feed management}

The system used for the rearing of rainbow trout Oncorhynchus mykiss Walbaum (1792) was raceway characterized by intensive production with high continuous water flow. The trout farming system was populated with 56,000 fish at different stages of development distributed in twelve masonry tanks (a meter deep) and separated into three sectors of production, the first with 40,000 fingerlings (average weight of $2 \mathrm{~g}$ ), distributed into four tanks $2 \mathrm{~m}^{3}$ (cubic meter) each; the second with 10,000 juveniles (average weight of $20 \mathrm{~g}$ ), distributed into four tanks of $5 \mathrm{~m}^{3}$ each and the third with 6,000 adults (average weight of $200 \mathrm{~g}$ ), distributed into four tanks of $19 \mathrm{~m}^{3}$ each (see Figure 1A). In all tanks the feeding was performed by the producer twice or three times daily with extruded ration containing $40 \%$ of crude protein (see Table 1), considering the stage of development of individuals and an estimated total biomass (fingerlings - from 5 to $7 \%$ of total biomass; juveniles and adults - from 3 to $5 \%$ of total biomass).

\subsection{Sampling and limnological variables}

The analysis were performed from 2 September to 25 November 2010 weekly in triplicate at six points $(n=13)$. The distribution of sampling points (see Figure 1B) followed the order: $\mathrm{S} 1$ = upstream production system; $\mathrm{S} 2$ = affluent; $\mathrm{S} 3$ = effluent; $\mathrm{S} 4=$ outlet after passing by the wetland (area 


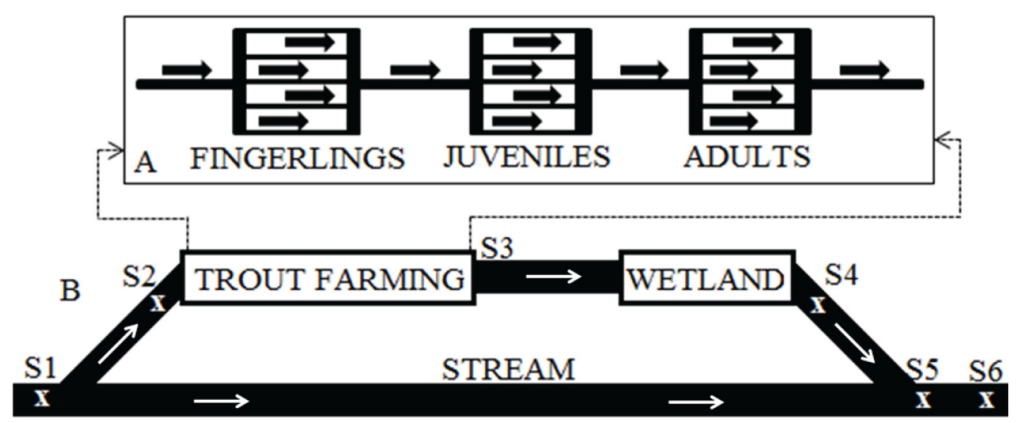

Figure 1. $A=$ Representation of the organized trout farming system in three sectors: fingerlings, juveniles and adults; $\mathrm{B}=$ Schematic drawing of the trout farming system located in the Serra da Bocaina (SP), where: S1 = upstream production system; S2 = affluent; S3 = effluent; S4 = outlet after passing by the wetland; S5 = mixing zone; S6 = in the receiving water body (stream), 60 meters away from the effluent. Adapted from Caramel et al. (2014).

Table 1. Characteristics of feed offered to fish in trout farming system.

\begin{tabular}{lc}
\hline & Assurance levels \\
\hline Humidity $\left(\mathrm{g} \mathrm{kg}^{-1}\right.$ of feed $)$ & 100.00 \\
Crude protein $\left(\mathrm{g} \mathrm{kg}^{-1}\right.$ of feed $)$ & 400.00 \\
Ethereal extract $\left(\mathrm{g} \mathrm{kg}^{-1}\right.$ of feed $)$ & 120.00 \\
Crude fiber $\left(\mathrm{g} \mathrm{kg}^{-1}\right.$ of feed $)$ & 45.00 \\
Mineral matter $\left(\mathrm{g} \mathrm{kg}^{-1}\right.$ of feed $)$ & 130.00 \\
Calcium $\left(\mathrm{g} \mathrm{kg}^{-1}\right.$ of feed $)$ & 20.00 \\
Phosphorus $\left(\mathrm{g} \mathrm{kg}^{-1}\right.$ of feed $)$ & 10.00 \\
Folic acid $\left(\mathrm{g} \mathrm{kg}^{-1}\right.$ of feed $)$ & 6.00 \\
\hline
\end{tabular}

of $100 \mathrm{~m}^{2}$, depth of $2 \mathrm{~m}$ and with presence of Thypha sp and aquatic grass); S5 = mixing zone; S6 = in the receiving water body (stream), 60 meters away from the effluent.

Water samples were collected in the subsurface water column. Samples for analysis of the totals (phosphorus and nitrogen) were frozen. Samples for analysis of dissolved fraction were immediately filtered in vacuum pump using GFF Whatman filters with porosity of $0.47 \mu \mathrm{m}$ and after they were frozen. In the laboratory, the samples were analyzed for concentration of total phosphorus $\left(\mu \mathrm{g} \mathrm{L}^{-1}\right)$ and total nitrogen $\left(\mu \mathrm{g} \mathrm{L}^{-1}\right)$ according to the methodology described by Valderrama (1981), orthophosphate $\left(\mu \mathrm{g} \mathrm{L}^{-1}\right)$ according to the methodology described by Strickland and Parsons (1960) and ammonium ( $\mu \mathrm{g} \mathrm{L}^{-1}$ ) according to the methodology described by Apha (2005). To calculate the water flow $\left(\mathrm{L} \mathrm{s}^{-1}\right)$ was used the float method proposed by Marques and Argento (1988).

\subsection{Environmental indicators}

Nutrient loads were determined by the product of the water flow values $\left(\mathrm{L} \mathrm{s}^{-1}\right)$ and the nutrient concentrations (total phosphorus - TP, orthophosphate - $\mathrm{PO}_{4}-\mathrm{P}$, total nitrogen - TN and ammonium - $\left.\mathrm{NH}_{4}-\mathrm{N}\right)\left(\mu \mathrm{g} \mathrm{L}^{-1}\right)$ in affluent $\left(\mathrm{L}_{\mathrm{A}}\right)$ and in effluent $\left(\mathrm{L}_{\mathrm{E}}\right)$ of trout farming system, through the following Equation 1:

$\mathrm{L}=[] \times \mathrm{W}_{\mathrm{F}}$

where $\mathrm{L}=$ loads of $\mathrm{TP}, \mathrm{PO}_{4}-\mathrm{P}, \mathrm{TN}$ and $\mathrm{NH}_{4}-\mathrm{N}\left(\mathrm{kg} \mathrm{d}^{-1}\right)$, [ ] = nutrient concentrations $\left(\mu \mathrm{g} \mathrm{L}^{-1}\right), \mathrm{W}_{\mathrm{F}}=$ water flow $\left(\mathrm{L} \mathrm{s}^{-1}\right)$.
Subsequently, to quantify the amount of waste generated by the activity of trout farming, mass balance was calculated $\left(\mathrm{kg} \mathrm{d}^{-1}\right)$ of TP, $\mathrm{PO}_{4}-\mathrm{P}, \mathrm{TN}$ e $\mathrm{NH}_{4}-\mathrm{N}$ through the nutrient load that leaves via effluent and subtracted from the water supply system, according to the Equation 2:

$\mathrm{MB}_{\mathrm{L}}=\mathrm{L}_{\mathrm{E}}-\mathrm{L}_{\mathrm{A}}$

where $\mathrm{MBL}=$ mass balance among loads of TP, $\mathrm{PO}_{4}-\mathrm{P}$, $\mathrm{TN}$ and $\mathrm{NH}_{4}-\mathrm{N}\left(\mathrm{kg} \mathrm{d}^{-1}\right), \mathrm{L}_{\mathrm{E}}=$ the considered variable load in the effluent of the system $\left(\mathrm{kg} \mathrm{d}^{-1}\right), \mathrm{L}_{\mathrm{A}}=$ the considered variable load in the affluent of the system $\left(\mathrm{kg} \mathrm{d}^{-1}\right)$.

Throughout the study period (three months), at harvesting, the fish were counted and weighed to obtain the total productivity of trout. The feed conversion ratio of the production system was estimated thought the relation between the total of feed offered and the quantity of fish taken in each harvesting.

The nutrient load of production system via feeding was estimated by the amount of phosphorus and nitrogen contained in the total feed offered (Equation 3), of the levels of these nutrients that were converted into fish biomass (Equation 4) and of the lost via effluent (Equation 5) (Boyd and Queiroz, 2001; Boyd et al., 2007). It was assumed that the trout presents $25 \%(0.25 \mathrm{~kg})$ of dry matter, whereas the dry matter containing $3.2 \%(0.032 \mathrm{~kg})$ of phosphorus and $10 \%(0.10 \mathrm{~kg})$ of nitrogen (Boyd and Queiroz, 2001; Boyd et al., 2007). The commercial feeds used in trout farming system contained $1.0 \%(0.010 \mathrm{~kg})$ of phosphorus and $4.0 \%(0.040 \mathrm{~kg})$ of nitrogen per $\mathrm{kg}$ of feed. For the calculations, it was assumed that $5 \%$ of the total feed offered were lost as food not eaten (Bureau et al., 2003). Whereas the production of fish and feed offered, were applied in the present study the following Equations 3 and 4:

$\mathrm{I}_{\mathrm{F}}=\mathrm{F}_{\mathrm{O}} \times \mathrm{N}_{\mathrm{F}}$

where $\mathrm{I}_{\mathrm{F}}=$ input of nutrient via feed $\left(\mathrm{kg} \mathrm{period}^{-1}\right.$ of $\mathrm{P}$ or $\left.\mathrm{N}\right)$, $\mathrm{F}_{\mathrm{O}}=$ amount of feed offered $\left(\mathrm{kg}_{\text {period }}{ }^{-1}\right), \mathrm{N}_{\mathrm{F}}=$ amount of nutrient $(\mathrm{kg})$ by kilogram of feed.

$\mathrm{N}_{\mathrm{B}}=\mathrm{P} \times \mathrm{DM} \times \mathrm{N}_{\mathrm{DM}}$ 
where $\mathrm{N}_{\mathrm{B}}=$ converted nutrient in fish biomass ( $\mathrm{kg}$ of $\mathrm{P}$ or $\mathrm{N}$ ), $\mathrm{P}=$ fish production $(\mathrm{kg}), \mathrm{DM}=$ amount of dry matter by kilogram of fish (kg), $\mathrm{N}_{\mathrm{DM}}=$ amount of nutrient $(\mathrm{P}$ or $\mathrm{N})$ by kilogram of dry matter of fish $(\mathrm{kg})$.

To calculate the amount of TP and TN of feed lost via the effluent in the production system during the study period (three months) was applied the following Equation 5:

$\mathrm{MB}_{\mathrm{F}}=\mathrm{I}_{\mathrm{F}}-\mathrm{N}_{\mathrm{B}}$

where $\mathrm{MB}_{\mathrm{F}}=$ mass balance between input of nutrients via feed and the amount of the converted nutrients in fish biomass $\left(\mathrm{kg}\right.$ period ${ }^{-1}$ of $\mathrm{P}$ or $\left.\mathrm{N}\right), \mathrm{I}_{\mathrm{F}}=$ input of nutrients via feed $\left(\mathrm{kg}_{\text {period }}{ }^{-1}\right.$ of $\mathrm{P}$ or $\left.\mathrm{N}\right), \mathrm{N}_{\mathrm{B}}=$ converted nutrients in fish biomass ( $\mathrm{kg}$ of $\mathrm{P}$ or $\mathrm{N})$.

\subsection{Statistical analysis}

The data of nutrients concentrations after log transformation $(\mathrm{x}+1)$ were analyzed using the Kruskal-Wallis test followed by the Student-Newman-Keuls (SNK) test to verify the spatial variations (Zar, 2010). The adopted significance level was 0.05 .

\section{Results}

The trout farming studied used raceway system, receiving constant flow of water with average water flow of $38.26 \mathrm{~L} \mathrm{~s}^{-1}$, maintaining residence time around $1 \mathrm{~h}$ $40 \mathrm{~min}$ throughout the system.

The total phosphorus $(\mathrm{H}=154.67$; $\mathrm{P}<0.001)$, orthophosphate $(\mathrm{H}=127.47 ; \mathrm{P}<0.001)$, total nitrogen
$(\mathrm{H}=20.79 ; \mathrm{P}=0.001)$ and ammonium $(\mathrm{H}=57.33$; $\mathrm{P}<0.001)$ demonstrated spatial variations through SNK test (see Figure 2).

Has occurred the formation of two distinct patterns [S1 and S2] and [S3, S4, S5 and S6] $(\mathrm{p}<0.05)$ related to the nutrients. After passage through the production system was increased from the upstream of production system (S1) to effluent of system (S3), without retaining effect on wetland (S4), with small dilution in concentrations when the effluent reached the receiving water body (S5 and S6).

When the nutrient loads were calculated, stood out the amount of total phosphorus, orthophosphate, total nitrogen and ammonium in effluent of the system (see Figure 3 ). The mass balance calculation showed that trout production exported in average $8.27 \mathrm{~kg} \mathrm{TP}, 5.74 \mathrm{~kg} \mathrm{PO}_{4}-\mathrm{P}, 36.95 \mathrm{~kg} \mathrm{TN}$ and $28.11 \mathrm{~kg} \mathrm{NH}_{4}-\mathrm{N}$ during the study period (3 months).

During the study period were offered $2,475 \mathrm{~kg}$ of feed with a production of $1,165 \mathrm{~kg}$ of fish. The average feed conversion of the system was 2.12:1. Of the offered feed during the study period, $24.75 \mathrm{~kg}(100 \%)$ were available as $\mathrm{P}$ and of these, $9.32 \mathrm{~kg} \mathrm{P}(38 \%)$ were converted into fish biomass and $15.43 \mathrm{~kg} \mathrm{P}(62 \%)$ were exported via effluent, being $1.24 \mathrm{~kg} \mathrm{P}(5 \%)$ in non-feed intake and $14.19 \mathrm{~kg} \mathrm{P}$ (57\%) arising from the fish metabolism (see Figure 4a). Related to TN (see Figure 4b), $99.00 \mathrm{~kg} \mathrm{~N} \mathrm{(100 \% )} \mathrm{were}$ offered via feed throughout of study period, of these, $29.12 \mathrm{~kg} \mathrm{~N}(25 \%)$ were converted into fish biomass and $69.88 \mathrm{~kg} \mathrm{~N}(75 \%)$ were exported via effluent, being $5.94 \mathrm{~kg} \mathrm{~N}(5 \%)$ in non-feed intake and $63.94 \mathrm{~kg} \mathrm{~N}(70 \%)$ arising from the fish metabolism.
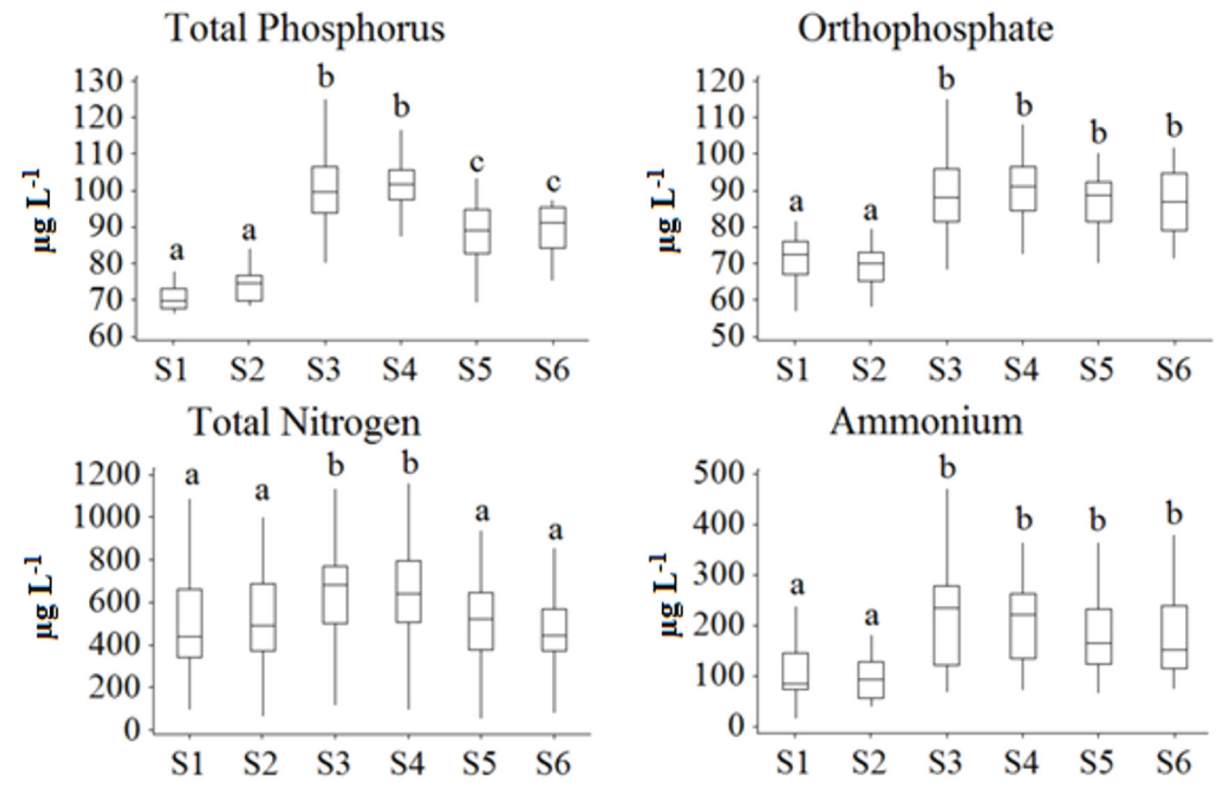

Figure 2. Nutrients analyzed during the study period in trout farming system in samplings sites $\mathrm{S} 1=$ upstream production system; S2 = affluent; S3 = effluent; S4 = outlet after passing by the wetland; S5 = mixing zone; S6 = in the receiving water body (stream), 60 meters away from the effluent, represented by Box-Whiskers Plot where the lower and upper limits of the Box correspond to the 25 and 75 percentiles, the whiskers correspond to the minimum and maximum, and the center line of distribution correspond to the median. Medians followed by the same letter do not differ by SNK test $(0.05)$. 

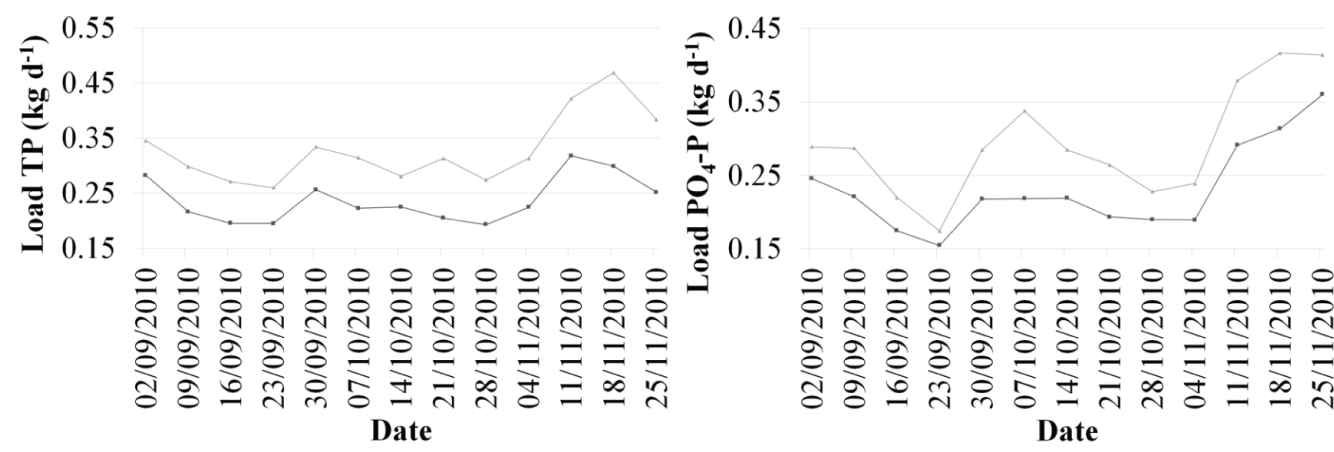

ซ్ 0.15
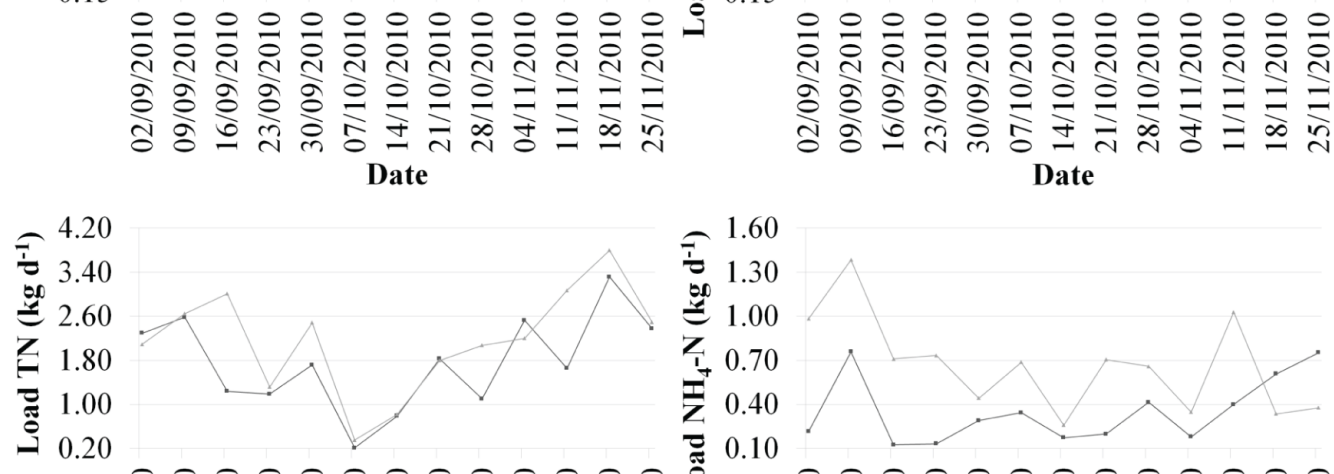

Date

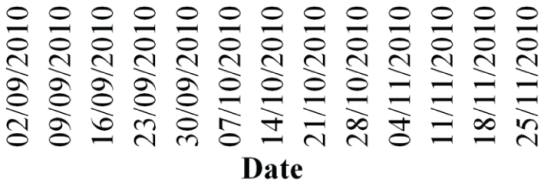

- Affluent

$\neq$ Effluent
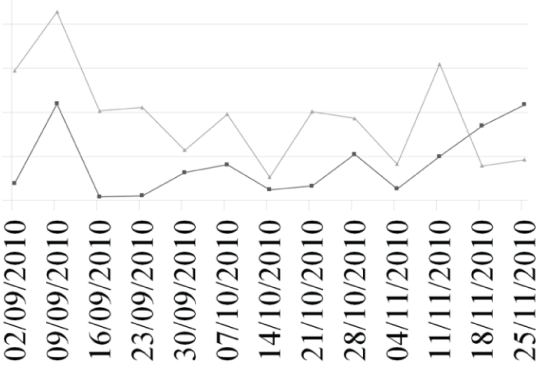

Date

Figure 3. Nutrient loads, total phosphorus (TP), orthophosphate $\left(\mathrm{PO}_{4}-\mathrm{P}\right)$, total nitrogen $(\mathrm{TN})$ and ammonium $\left(\mathrm{NH}_{4}-\mathrm{N}\right)(\mathrm{kg}$ $\mathrm{d}^{-1}$ ), in affluent (black) and effluent (gray) of the trout farming system throughout the study period.
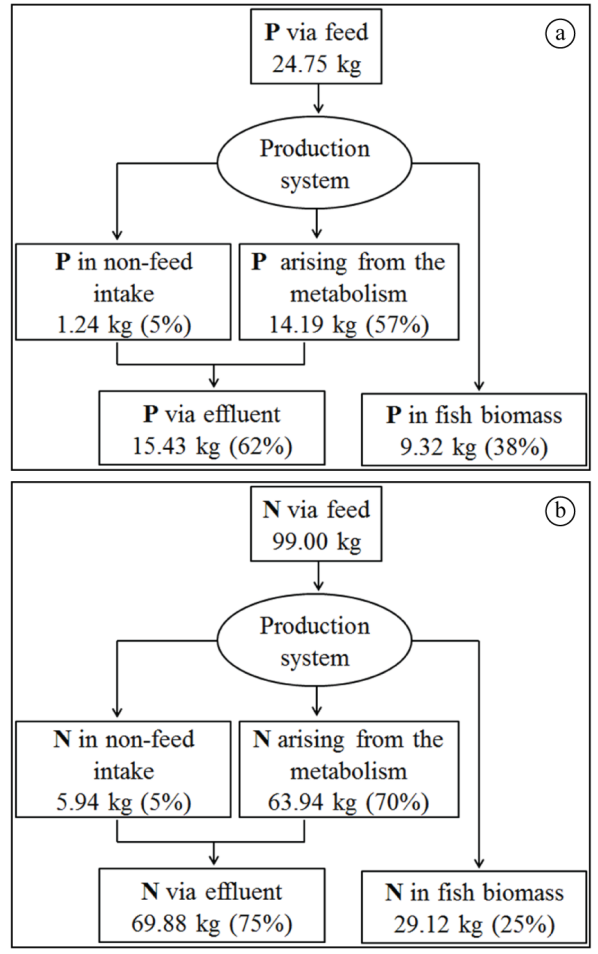

Figure 4. Nutrient fluxes in intensive trout farming system during the study period (three months) $\left(\mathrm{kg}\right.$ period $\left.^{-1}\right)$ : $\mathrm{a}=$ total phosphorus $(\mathrm{TP}) ; \mathrm{b}=$ total nitrogen $(\mathrm{TN})$. Adapted from Wang et al. (2012).

\section{Discussion}

Although the studied system is considered small due to the availability of water (production up to twenty tons of trout per year), this is the profile of $70 \%$ of intensive trout farming systems located in the Southeast and Southern of Brazil.

The increments of the nutrients after passage through the production system $(\mathrm{S} 3)$ can be related to the feeding. On studies performed in tilapia farming (Araripe et al., 2006), in trout farming (Koçer et al., 2013; Amirkolaie, 2011) and in bullfrog farming (Mercante et al., 2014), the authors attributed the amount of nutrients to the wasted food and/or not used, use of unbalanced diet and fish metabolism.

After passing through the wetland (S4) there was no reduction in the concentrations of nutrients, indicating that the wetland was not efficient, which can be associated with the absence of management in this site. Among the different ways to improve this treatment system must consider its proportional scale to the production area and the residence time of the water (Caramel et al., 2014).

The trout farming's contribution related to nutrients concentrations on the receiving water body (S5 and S6) compared to upstream production system (S1) showed that the distance of $60 \mathrm{~m}$ was not enough to occur recovery of the receiving water body. This result might be related to the fact that more than half of the stream volume was directed to supply the trout farming system and that may have changed the stream metabolism. 
Through the mass balance calculation the trout farming was characterized as an export system of nutrients due to high loads of nutrients in the effluent resulting from the relation between high water flow and higher nutrient concentration in the effluent of system. This relation of water flow in determining the loads of nutrients is more evident when comparing different production systems. The average concentration of phosphorus in effluent of the study trout farming $\left(100.73 \mu \mathrm{g} \mathrm{L}^{-1}\right)$, when compared to the concentration of TP in effluent of bullfrog farming system $\left(6,090.00 \mu \mathrm{g} \mathrm{L}^{-1}\right)$ (Borges et al., 2012) was lower, however, the trout farming showed the highest load of TP via effluent $\left(0.33 \mathrm{~kg} \mathrm{TP} \mathrm{d^{-1 }}\right)$ due to the greater water flow $\left(38.26 \mathrm{~L} \mathrm{~s}^{-1}\right)$ when compared to the bullfrog farming (load of $0.01 \mathrm{~kg} \mathrm{TP} \mathrm{d}^{-1}$ and water flow of $0.02 \mathrm{~L} \mathrm{~s}^{-1}$ ).

In Brazil, studies performed in bullfrog farming (Mercante et al., 2014; Borges et al., 2012) and in polyculture system (tilapia and shrimps) (Araújo-Silva et al., 2014), showed that quantification of loads can be a useful tool for characterizing the impact, since it contemplates the flow and not only nutrient concentrations. This allows the comparison of different systems, methods of creation and evaluation of the effectiveness of management practices used in the production system (Boyd et al., 2007).

Regarding the P retained in the trout biomass (38\%) (Figure 4a), the value was higher than those obtained by Wang et al. (2012) in salmon farming industry in Norway $(30 \%)$ and Bartoli et al. (2007) in trout farming system in Italy (19\%). Related to the $\mathrm{N}$ retained in trout biomass (25\%) (Figure $4 \mathrm{~b}$ ), the values were lower than those obtained by Wang et al. (2012) (38\%), Bartoli et al. (2007) (49\%) and Noròi et al. (2011) in trout farming in the Faroe Islands (32\%). These results can be explained by the difference in the composition of diets, feed management (quantity and quality of feed offered, time and feeding frequency throughout the day) and fish metabolism (Bureau et al., 2003; Coloso et al., 2001; Tello et al., 2010).

The amount of $\mathrm{P}$ and $\mathrm{N}$ exported via effluent $(62 \%$ and $75 \%$, respectively) indicates that the largest amount of the nutrients that entered via feed were discarded in the aquatic environment, because for each kilogram of feed offered, $6.23 \mathrm{~g}$ TP and $28.23 \mathrm{~g}$ TN were discharged via effluent. The production of waste arising from the aquaculture may be reduced based on nutritional strategies, as in the formulation of nutrients and the development of efficient feeding systems based on energy requirements of the species (Bouwman et al., 2013).

Such estimates can be corroborated by the result of feed conversion (2.12:1) that demonstrated excessive discharge of nutrients via effluent related to the leftover of the feed offered and to the low retention in fish biomass. The reduction of feed conversion ratio from 2.1:1 (similar to the present study) to $1.7: 1$ can lead to a $20 \%$ reduction in waste from aquaculture (Mungkung et al., 2013), factor related to environmental issues, since it is related to fish metabolism (absorption and excretion of nutrients), interfering with the concentrations of organic matter (Cyrino et al., 2010). Therefore, if the feed conversion of trout farming was 1.7:1, the system would export $4.98 \mathrm{~g}$ TP and $22.58 \mathrm{~g}$ TN per kilogram of feed instead of $6.23 \mathrm{~g}$ TP and $28.23 \mathrm{~g}$ TN per kilogram of feed. From these results it is proposed from this study using the FCR, besides of production indicator, include it as an environmental indicator.

The loads and the mass balance show the excessive discharge of nutrients via effluent, corroborated by the feed conversion ratio $(2.12: 1)$ due to the low efficiency of feed utilization, therefore, it is proposed the use of this zootechnical parameter as environmental indicator. In addition, feed management practices are not adequate, highlighting the low frequency of feeding during the day, excessive amount and low quality of feed offered. Therefore, in order to reduce this excessive discharge in the receiving water body are recommended adjustments in management, as improvement in phosphorus and nitrogen assimilation considering the fish stage of development, amount control of the feed offered, use of appropriate stocking densities and effluent treatment.

\section{Acknowledgements}

We thank to Dr. Marcos Guilherme Rigolino, Scientific Researcher at the Experimental Station of Trout Farming, in memoriam, by participation in the analysis of results, to CAPES (Coordination of Higher Education Personnel Training) by the Masters scholarship, to CNPq by the research productivity scholarship to André Martins Vaz dos Santos (305403/2015-0) and to FAPESP (Research Support Foundation in São Paulo) by financial support (2010/07658-3).

\section{References}

ABIMORAD, E.G., GONÇALVES, G.S. and CASTELLANI, D., 2012. A crise dos alimentos e os reflexos na aquicultura brasileira. Pesquisa e Tecnologia, vol. 9, no. 2, pp. 1-4.

AMERICAN PUBLIC HEALTH ASSOCIATION -APHA, 2005. Standard methods for the examination of water and wastewater. 21 st ed. Washington: American Water Works Association/Water Pollution Control Federation. 1085 p.

AMIRKOLAIE, K.A., 2011. Reduction in the environmental impact of waste discharged by fish farms through feed and feeding. Rev. Aquacult., vol. 3, no. 1, pp. 19-26. http://dx.doi. org/10.1111/j.1753-5131.2010.01040.x.

ARARIPE, M.N.B.A., SEGUNDO, L.F.F., LOPES, J.B. and ARARIPE, H.G.A., 2006. Efeito do cultivo de peixes em tanques rede sobre o aporte de fósforo para o ambiente. Revista Científica de Produção Animal, vol. 8, no. 2, pp. 56-65.

ARAÚJO-SILVA, S.L., MORAES, M.A.B., CARMO, C.F., OSTI, J.A.S., VAZ-DOS-SANTOS, A.M. and MERCANTE, C.T.J., 2014. Effluent of a polyculture system (tilapias and shrimps): assessment by mass balance of nitrogen and phosphorus. Journal of Environmental Protection, vol. 5, no. 10, pp. 799-804. http:// dx.doi.org/10.4236/jep.2014.510081.

BAIRD, D.J., BEVERIDGE, M.C.M., KELLY, L.A. and MUIR, J.F., 1996. Aquaculture and water resource management. London: Blackwell Science Ltd. 219 p. 
BARTOLI, M., NIZZOLI, D., LONGHI, D., LAINI, A. and VIAROLI, P., 2007. Impact of a trout farm on the water quality of an Apennine Creek from daily budgets of nutrients. Chemistry and Ecology, vol. 23, no. 1, pp. 1-11. http://dx.doi. org/10.1080/02757540601084003.

BERGHEIM, A. and BRINKER, A., 2003. Effluent treatment for flow through systems and European environmental regulations. Aquacultural Engineering, vol. 27, no. 1, pp. 61-77. http://dx.doi. org/10.1016/S0144-8609(02)00041-9.

BOAVENTURA, R., PEDRO, A.M., COIMBRA, J. and LENCASTRE, E., 1997. Trout farm effluents: characterization and impact on the receiving streams. Environmental Pollution, vol. 95, no. 3, pp. 379-387. http://dx.doi.org/10.1016/S02697491(96)00117-0. PMid:15093453.

BORGES, F.F., AMARAL, L.A. and DE STEFANI, M.V., 2012. Characterization of effluents from bullfrog (Lithobates catesbeianus, Shaw, 1802) grow-out ponds. Acta Limnologica Brasiliensia, vol. 24, no. 2, pp. 160-166. http://dx.doi.org/10.1590/ S2179-975X2012005000035.

BOUWMAN, A.F., BEUSEN, A.H.W., OVERBEEK, C.C., BUREAU, D.P., PAWLOWSKI, M. and GLIBERT, P.M., 2013. Hindcasts and future projections of global inland and coastal nitrogen and phosphorus loads due to finfish aquaculture. Reviews in Fisheries Science, vol. 21, no. 2, pp. 112-156. http://dx.doi.or $\mathrm{g} / 10.1080 / 10641262.2013 .790340$

BOYD, C.E. and QUEIROZ, J., 2001. Feasibility of retention structure, settling basins and best management practices in effluent regulation for Alabama channel catfish farming. Reviews in Fisheries Science, vol. 9, no. 2, pp. 43-67. http://dx.doi. org/10.1080/20016491101708.

BOYD, C.E., TUCKER, C., MCNEVIN, A., BOSTICK, A. and CLAY, J., 2007. Indicators of resource use efficiency and environmental performance in fish and crustacean aquaculture. Reviews in Fisheries Science, vol. 15, no. 4, pp. 327-360. http:// dx.doi.org/10.1080/10641260701624177.

BRASIL. CONSELHO NACIONAL DO MEIO AMBIENTE CONAMA, 2005 [viewed 20 March 2014]. Resolução 357 de 17 de março de 2005 [online]. Brasília: CONAMA. 24 p. Available from: http://www.mma.gov.br/port/conama/res/res05/res35705.pdf

BRASIL. CONSELHO NACIONAL DO MEIO AMBIENTE CONAMA, 2011 [viewed 21 March 2014]. Resolução 430 de 13 de maio de 2011 [online]. Brasília: CONAMA. 9 p. Available from: http://www.mma.gov.br/port/conama/legiabre.cfm?codlegi=646.pdf

BUREAU, D.P., GUNTHER, S.J. and CHO, C.Y., 2003. Chemical composition and preliminary theoretical estimates of waste outputs of rainbow trout reared in commercial cage culture operations in Ontario. North American Journal of Aquaculture, vol. 65, no. 1, pp. 33-38. http://dx.doi.org/10.1577/1548-8454(2003)065<0033:CC APTE $>2.0 . \mathrm{CO} ; 2$.

CARAMEL, B.P., MORAES, M.A.B., CARMO, C.F., VAZDOS-SANTOS, A.M., TABATA, Y.A., OSTI, J.A.S., ISHIKAWA, C.M., CERQUEIRA, M.A.S. and MERCANTE, C.T.J., 2014. Water quality assessment of a trout farming effluent, Bocaina, Brazil. J. Journal of Water Resource and Protection, vol. 6, no. 10, pp. 909-915. http://dx.doi.org/10.4236/jwarp.2014.610086.

COLOSO, R.M., BASANTES, S.P., KING, K., HENDRIX, M.A., FLETCHER, J.W., WEIS, P. and FERRARIS, R.P., 2001. Effect of dietary phosphorus and vitamin D3 on phosphorus levels in effluent from the experimental culture of rainbow trout (Oncorhynchus mykiss). Aquaculture (Amsterdam, Netherlands), vol. 202, no. 1-2, pp. 145-161. http://dx.doi.org/10.1016/S00448486(01)00572-5.

CYRINO, J.E.P., BICUDO, A.J.A., SADO, R.Y., BORGHESI, R. and DAIRIK, J.K., 2010. A piscicultura e o ambiente - O uso de alimentos ambientalmente corretos em piscicultura. Revista Brasileira de Zootecnia, vol. 39, pp. 68-87. http://dx.doi. org/10.1590/S1516-35982010001300009.

FOOD AND AGRICULTURE ORGANIZATION OF THE UNITED NATIONS - FAO, 2014 [viewed 8 April 2014]. The state of world fisheries and aquaculture [online]. Rome: FAO. 243 p. Available from: http://www.fao.org/3/a-i3720e.pdf

GORLACH-LIRA, K., PACHECO, C., CARVALHO, L.C.T., MELO JÚNIOR, H.N. and CRISPIM, M.C., 2013. The influence of fish culture in floating net cages on microbial indicators of water quality. Brazilian Journal of Biology $=$ Revista Brasileira de Biologia, vol. 73, no. 3, pp. 457-463. http://dx.doi.org/10.1590/ S1519-69842013000300001. PMid:24212684.

HENARES, M.N.P. and CAMARGO, A.F.M., 2014. Treatment efficiency of effluent prawn culture by wetland with floating aquatic macrophytes arranged in series. Brazilian Journal of Biology $=$ Revista Brasileira de Biologia, vol. 74, no. 4, pp. 906-912. http:// dx.doi.org/10.1590/1519-6984.10413. PMid:25627602.

KOÇER, M.A.T., KANYILMAZ, M., YILAYAZ, A. and SEVGILI, H., 2013. Waste loading into a regulated stream from land-based trout farms. Aquaculture Environment Interactions, vol. 3, no. 3, pp. 187-195. http://dx.doi.org/10.3354/aei00059.

MACMILLAN, J.R., HUDDLESTON, T., WOOLLEY, M. and FOTHERGILL, K., 2003. Best management practice development to minimize environmental impact from large flow-through trout farms. Aquaculture (Amsterdam, Netherlands), vol. 226, no. 1-4, pp. 91-99. http://dx.doi.org/10.1016/S0044-8486(03)00470-8.

MARQUES, J.S. and ARGENTO, M.S.F., 1988. O uso de flutuadores para avaliação da vazão de canais fluviais. Geociências, vol. 7, pp. 173-186.

MERCANTE, C.T.J., VAZ-DOS-SANTOS, A.M., MORAES, M.A.B., PEREIRA, J.S. and LOMBARDI, J.V., 2014. Bullfrog (Lithobates catesbeianus) farming system: water quality and environmental changes. Acta Limnologica Brasiliensia, vol. 26, no. 1, pp. 9-17. http://dx.doi.org/10.1590/S2179-975X2014000100003.

MUNGKUNG, R., AUBIN, J., PRIHADI, T.H., SLEMBROUCK, J., VAN DER WERF, H.M. and LEGENDRE, M., 2013. Life cycle assessment for environmentally sustainable aquaculture management: a case study of combined aquaculture systems for carp and tilapia. Journal of Cleaner Production, vol. 57, pp. 249256. http://dx.doi.org/10.1016/j.jclepro.2013.05.029.

NORÒI, G., GLUD, R.N., GAARD, E. and SIMONSEN, K., 2011. Environmental impacts of coastal fish farming: carbon and nitrogen budgets for trout farming in Kaldbaksfjør7ur (Faroe Islands). Marine Ecology Progress Series, vol. 431, pp. 223-241. http://dx.doi.org/10.3354/meps09113.

NOROOZRAJABI, A., GHORBANI, R., ABDI, O. and NABAVI, E., 2013. The impact of rainbow trout farm effluents on water physicochemical properties of Daryasar Stream. World Journal of Fish and Marine Sciences, vol. 5, pp. 342-346. http://dx.doi. org/10.5829/idosi.wjfms.2013.05.03.72175.

STRICKLAND, J.D.H. and PARSONS, T.R.A., 1960. A manual of sea water analysis. Bulletin: Fisheries Research Board of Canada, vol. 125, pp. 1-185. 
TELLO, A., CORNER, R.A. and TELFER, T.C., 2010. How do land-based salmonid farms affect stream ecology? Environmental Pollution, vol. 158, no. 5, pp. 1147-1158. http://dx.doi.org/10.1016/j. envpol.2009.11.029. PMid:20036452.

VALDERRAMA, J.C., 1981. The simultaneous analysis of total nitrogen and phosphorus in natural water. Marine Chemistry, vol. 10, no. 2, pp. 109-122. http://dx.doi.org/10.1016/03044203(81)90027-X.
WANG, X., OLSEN, L.M., REITAN, K.I. and OLSEN, Y., 2012. Discharge of nutrient wastes from salmon farms: environmental effects, and potential for integrated multi-trophic aquaculture. Aquaculture Environment Interactions, vol. 2, no. 3, pp. 267-283. http://dx.doi.org/10.3354/aei00044.

ZAR, J.H., 2010. Biostatistical analysis. 5th ed. New Jersey: Pearson Prentice Hall. 944 p. 